Article

\title{
Value-Based Building Maintenance Practices for Public Hospitals in Malaysia
}

\author{
Wai Fang Wong ${ }^{1, * \mathbb{C}}$, AbdulLateef Olanrewaju ${ }^{2}$ and Poh $\operatorname{Im~Lim}^{3}$ \\ 1 Lee Kong Chian Faculty of Engineering \& Science, Sungai Long Campus, Universiti Tunku Abdul Rahman, \\ Selangor 43000, Malaysia \\ 2 Department of Construction Management, Universiti Tunku Abdul Rahman, Jalan Universiti, Bandar Barat, \\ Perak 31900, Malaysia; olanrewaju@utar.edu.my \\ 3 Department of Architecture \& Sustainable Design, Lee Kong Chian Faculty of Engineering \& Science, \\ Sungai Long Campus, Universiti Tunku Abdul Rahman, Selangor 43000, Malaysia; limpi@utar.edu.my \\ * Correspondence: Waifang.wong@gmail.com
}

Citation: Wong, W.F.; Olanrewaju, A.; Lim, P.I. Value-Based Building Maintenance Practices for Public Hospitals in Malaysia. Sustainability 2021, 13, 6200. https://doi.org/ $10.3390 /$ su13116200

Academic Editor:

Alberto-Jesus Perea-Moreno

Received: 28 April 2021

Accepted: 25 May 2021

Published: 31 May 2021

Publisher's Note: MDPI stays neutral with regard to jurisdictional claims in published maps and institutional affiliations.

Copyright: (c) 2021 by the authors. Licensee MDPI, Basel, Switzerland. This article is an open access article distributed under the terms and conditions of the Creative Commons Attribution (CC BY) license (https:// creativecommons.org/licenses/by/ $4.0 /)$.

\begin{abstract}
Public hospital buildings in Malaysia have been facing problems and have become subjects of public criticisms due to poor building maintenance practices. A value-based approach which integrates and assimilates the concepts of value can be applied to mitigate maintenance problems in hospital buildings. This study evaluated the causal relationships between value factors and value outcomes of building maintenance in public hospitals in Malaysia. A total of 66 samples were collected via an online questionnaire survey. Analysis was performed using partial least square structural equation modeling (PLS-SEM). Our results reveal that value-adding practices and value co-creation have a positive influence on value outcomes in hospitals. The findings, however, do not support the relationships between factors of user involvement and value outcomes, which merit further investigation. This study concludes that value-adding practice has the strongest impact on value outcomes. Thus, maintenance service providers should assimilate these practices in their services to enhance performance. In addition, the findings also justify the requirement for collaborative working arrangements for value co-creation of building maintenance.
\end{abstract}

Keywords: building performance; value co-creation; value add; maintenance management; hospital buildings

\section{Introduction}

Hospital buildings are primarily designed to provide healthcare functions such as curative nursing and rehabilitation. Hospital infrastructure must be reliable and support the daily functions to ensure continuous operations at all times, including crisis and disaster scenarios [1]. Healthcare premises also need to fulfill safety, comfort, security, and energy efficiency [2]. However, hospital buildings are challenging to maintain, primarily due to the complexity of their infrastructure [3,4]. Poor maintenance services of hospital buildings [5], and construction activities [6], can potentially affect patients' health. Building conditions such as defects were found to affect health problems in buildings [7]. In view of these highly functional requirements, the facilities must always be ready to support medical teams in their operations. Hence, it is important to ensure that hospital buildings are always maintained at an optimal state for excellent healthcare.

Globally, issues of maintenance and poor performance of hospitals have been reported in the extant literature. For instance, assessment of public hospitals in the Gaza Strip, Palestine found that most hospitals adopted corrective maintenance and did not carry out routine inspections for water and plumbing systems [8]. Low performance was reported on vertical transportation, fire protection, telecommunications, and electrical supply in Southwest Nigerian public hospital buildings [3]. An audit in Cuban hospitals also identified mismanagement of maintenance activities by staff in the maintenance department as 
the root cause of subsequent maintenance problems [9]. More recently, fire safety concerns in hospitals were raised where various fire incidents in Asia and globally were reported and maintenance of firefighting appliances were among the issues mentioned $[10,11]$.

In the context of Malaysia, the healthcare system is categorized into tax-funded public healthcare and private healthcare [12]. Public hospitals contribute 42,424 beds, amounting to $73 \%$ of the total hospital beds from 144 public hospitals and medical institutions in the country [13]. Efforts to standardize facilities management (FM) practices in public hospitals were initiated in 1996 through the privatization of hospital support services by only three concession companies (CCs), to improve the overall level of service [14]. The building maintenance component is parked under the facilities engineering maintenance services (FEMS), which is among the six hospital support services that are outsourced. Currently, there are five concession companies nationwide. The concession agreement (CA) was signed between the concession companies and the government, for up to 15 years.

However, despite having a comprehensive contract [15], and a long concession period, weaknesses in public hospital maintenance have persisted unabated. CCs were revealed to be inefficient, lacked competent manpower and training, and heavily rely on their subcontractors [16]. There was also inadequate support from the contractor's top management [16]. Besides that, the contract utilizes a deductive fee system on non-conformance and non-performance by CCs [14], to ensure compliance to contract requirements. This practice requires heavy supervision and monitoring by hospital staff [14]. It was reported that hospital engineers are required to monitor between 2109 and 6625 units of FEMS assets per hospital [17]. Issues of rising operation costs [18], also indicate a lack of value for money. Overall, the maintenance management system is transactional and contractual, and there is a lack of initiatives and collaborative effort among the parties involved, i.e., the contractors, building users and hospital maintenance teams.

In a span of 21 years, healthcare spending as a share of the gross domestic product (GDP) has increased from 3.03\% in 1997, to 4.24\% in 2017 [19]. Based on 2016 statistics, the spending per GDP for Malaysia is still far behind more developed countries such as France, Germany, Japan, Australia, and the United Kingdom, which spend 9\% to 11\% of GDP on healthcare [19]. Malaysia is also behind neighboring countries such as Singapore, the Philippines, China, Sri Lanka, and South Korea, but ahead of Thailand, India, Indonesia, and Bangladesh [19].

Despite a constant increase in the allocation of national budget and concession agreements, problems involving poor maintenance are increasing unabated. Some of the issues encountered are experienced in other countries as well [20]. They include budget constraints and high expenditures, customer satisfaction, and complex information and decision-making. Past research works concentrating on hospital building maintenance are fragmented and lean towards the "hard" aspects such as, but not limited to, maintenance strategies, maintenance cost, and overall efficiency. The most researched topics in healthcare facilities management were categorized into IT and decision-making, maintenance costs, sourcing and contracts, and performance measurement [20].

There is a dearth of literature that attempts to explore the potential impact of value concepts as an alternative solution to resolve maintenance issues, particularly in the context of healthcare buildings such as hospitals. Hence, this study assesses the factors contributing to the improvement of maintenance from the aspects of user involvement, value-adding practices, and value co-creation. This research investigates value concepts in a holistic and integrated model for hospital maintenance which have not been explicitly addressed previously. Specifically, the causal relationships between value factors and the value outcomes of hospital maintenance are determined to fill the gap in empirical studies. 


\section{Literature Review}

Internationally, research on hospital maintenance focused on several aspects such as maintenance efficiencies in Israel [21], maintenance manpower in UK hospitals [22], budgeting for university hospitals in Italy [23], building maintenance systems [24], and operational maintenance in Palestine [8]. Recent research trends have dealt with customer satisfaction and service quality $[25,26]$, and performance [27]. Fire safety issues in Asia [10], and automated maintenance systems [28], were investigated. The value-based approach is limited to the aspect of value-adding facilities management in the UK [29].

Similarly, in the Malaysian context, past research on hospital building maintenance is limited and fragmented in various areas, e.g., quality management [30], outsourcing costs [18], audit assessment [16], critical success factors in facilities management [31,32], maintenance strategies [33], and maintenance effectiveness [34]. Recent trends on sustainability and energy saving [35,36], and green hospitals have gained attention [37]. Overall, research on value concepts in building maintenance context is still relatively scarce and lacks theoretical and empirical justifications [4]. A value-based model for building maintenance were developed [38]; however, it is in the context of Malaysian educational buildings and focused on maintenance management functions instead of value-based factors.

The privatization of facilities management services of hospitals in 1996 underscored the Malaysian Government's commitment to combat maintenance issues in public hospitals. However, after two decades of implementation, the performance of hospital buildings is still subject to public criticism. Empirical evidence on building condition assessment revealed that facilities for "Persons with Disabilities" in public hospitals were critical [39], while poor maintenance of fire safety was pointed out as frequent incidences in hospitals [40]. The annual Auditor General's Report has disclosed defect issues, contamination, and failure of facilities [41], planned preventive maintenance and supervision issues in FEMS [17], and high dependency on third-party contractors to rectify defects [42]. Many of the reported problems were preventable and arose explicitly from weaknesses in maintenance management $[4,14]$. They were likely caused by low-performing contractors, lack of understanding of user expectations [4,43], and lack of emphasis on collaborative working. The maintenance process involves the constant interaction of various systems and parties. Therefore, it is vital to investigate the problems derived from maintenance management from each party individually, as well as from the effect of their collaboration. This encompasses the demand side, supply side, and collaborative working holistically, rather than uni-dimensionally. Value concepts which have gained attention in other industries can potentially help to mitigate problems in maintenance management. However, the valuebased approach in hospital maintenance, though promising, remains under-researched. Hence, this study addresses the pertinent research deficiency in the value-based approach for the case of hospital buildings.

The objective of this study is to assess the causal relationships between three value factors (i.e., user involvement, value add, and value co-creation) and value outcomes. The three value factors were investigated from the demand side (user involvement), supply side (value-adding practices) and the collaborative working (value co-creation) perspectives.

\subsection{User Involvement}

From the demand side, users refer to medical staff, and administrative or support staff who use the hospital facilities to perform day-to-day functions in providing healthcare services to patients. Prior studies provided insight on the needs for the active involvement of users as "partners" rather than as the end recipients of the service $[4,43]$. This view is in line with the proposition to co-opt customers' competency to increase business competitiveness [44]. The end users are the most unsatisfied stakeholders because their opinions were not heard before decisions were made [45]. The user value system "VALUCRITE" were developed to assess the criteria for academic institutions to enhance user satisfaction toward the maintenance process [46,47]. It is also crucial to measure user satisfaction $[26,38,48]$, to determine whether maintenance services are delivered up 
to their expectations, and whether there is a gap for any potential improvement. User perceptions should be viewed holistically rather than uni-dimensionally, from their input and expectation, workplace functionality and productivity, and to their satisfaction [49]. However, user involvement needs to be at an appropriate level, to avoid detracting them from their core business roles [49]. Hence, formal user involvement aids the achievement of the objectives of maintenance in hospitals. Thus, in this study, it is hypothesized that user involvement has a positive influence on the value outcomes as follows:

Hypothesis 1 (H1). User involvement positively influences value outcomes.

\subsection{Value-Adding Practices}

The value-adding concept refers to the supply side of the maintenance arrangement. Maintenance service providers are expected to deliver beyond basic transactional maintenance functions. Since building maintenance is a form of service, the role of service providers is crucial to ensure the service is delivered effectively. As the sole service provider, the appointed contractors should be competent, well equipped, and prepared to add value in their services. In the UK, National Healthcare Services (NHS), through partnering arrangements, offer the best value for money, and introduced innovative practices to achieve better service quality and overall corporate image [29]. The reliability of service partners and their ability to solve problems and provide service solutions are identified as factors in value creation for services [50]. Responsiveness to needs is another crucial aspect that customers value in their service partners [38]. Thus, this study explores the proposition that value-adding practices have a positive influence on value outcomes. Hypothesis 2 is presented as follows:

Hypothesis 2 (H2). Value-adding practices positively influence value outcomes.

\subsection{Value Co-Creation}

Value can be co-created through collaborative working. Businesses should shift from traditional company-centric value creation to a new co-creation of unique value with customers [44]. Customers' roles evolved from passive receivers, to be more engaging, active, informed and connected. Value co-creation is a direct result of the interaction among the parties involved [51]. Besides, value co-creation within FM is viewed as a new paradigm of research [52]. In other industries, value creation was explored by investigating collaboration in a different arrangement [53]. A value matrix framework was also proposed in the fashion industry [54]. In the IT industry, value drivers for client and service providers were explored [55], while a strong impact of value co-creation to outsourcing satisfaction was found [56]. Value co-creation can be achieved through the sharing of information [57], intensive cooperation [52], knowledge transfer [55,57], effective communication [52], openness and honesty, and mutual trust and confidence [58], relationship synergies [50], strategic integration [53], strategic alignment [55], and strong governance [58]. Thus, this study explored the proposition that value co-creation has a positive influence on value outcomes as follows:

Hypothesis 3 (H3). Value co-creation positively influences value outcomes.

Table 1 presents the three value factors and their sub-factors. 
Table 1. Value factors.

\begin{tabular}{cccc}
\hline Factor & Code & Sub-Factor & Literature Source \\
\hline \multirow{3}{*}{ User Involvement } & USE1 & User's Expectation & {$[38,45,52,59]$} \\
& USE2 & User's Involvement & {$[26,38,45,59]$} \\
& USE3 & User's Satisfaction & {$[38,48]$} \\
& VAL1 & Integrated Service Solutions & {$[50]$} \\
Value Adding Practices & VAL2 & Innovative Improved Practices & {$[29]$} \\
& VAL3 & Value for Money & {$[29]$} \\
& VAL4 & Cost Reduction/Saving & {$[38,60]$} \\
& VAL5 & Responsive to Needs & {$[52,53,57]$} \\
& JOR1 & Sharing of Resources & {$[57]$} \\
& JOR2 & Joint Technology & {$[53]$} \\
& JOR3 & Sharing of Information & {$[52]$} \\
& OPE1 & Operational Integration & {$[55,58]$} \\
& OPE2 & Intensive Cooperation & {$[52]$} \\
& OPE3 & Knowledge Transfer & {$[53,55]$} \\
& COM1 & Effective Communication & {$[60]$} \\
& COM2 & Transparency of Internal Information & {$[53,55]$} \\
& COM3 & Openness and Honesty & {$[60]$}
\end{tabular}

\subsection{Value Outcomes}

Value outcomes are what customers perceive, are determined by the beneficiary, and should be viewed holistically [61]. Besides focusing on fulfilling customer satisfaction, the aspects of the organization's wealth generation are important [53]. There are three levels of value outcomes: transactional, business, and strategic outcomes [55]. In the context of public hospitals, business outcomes, or wealth generation are not the objectives. However, the sustainability of hospitals is an important criterion. Hence, in this study, value outcomes for public hospital maintenance are two-fold, emphasizing on daily (1) operational outcomes and (2) strategic outcomes. Operational value outcomes refer to the short-term routine goals to ensure smooth day-to-day operations in the hospital, such as the daily work process. Strategic value outcomes require long-term development as a result of the collaborative effort of parties within the arrangement. Through synergetic actions, the service provider is entrusted with more roles, and treated as a partner in the relationship [55]. Table 2 presents the value outcomes. Figure 1 illustrates the conceptual model for this study.

Table 2. Value outcomes.

\begin{tabular}{cccc}
\hline Category & Code & Value Outcomes & Literature source \\
\hline \multirow{3}{*}{ Operational } & OVO1 & Daily Work Process & {$[55]$} \\
& OVO2 & Quality of Output & {$[53]$} \\
& OVO3 & Response Time & {$[53,55]$} \\
& OVO4 & Reduced Risk & {$[53]$} \\
& OVO5 & Health and Safety & {$[50]$} \\
& SVO1 & Skill and Knowledge & {$[53]$} \\
Strategic & SVO2 & Technology & {$[53]$} \\
& SVO3 & Contractor as Partner & {$[55]$} \\
& SVO4 & Performance & {$[47]$} \\
& SVO5 & User Satisfaction & {$[29,46,53,59]$} \\
& SVO6 & Corporate Image & {$[29]$} \\
\hline
\end{tabular}




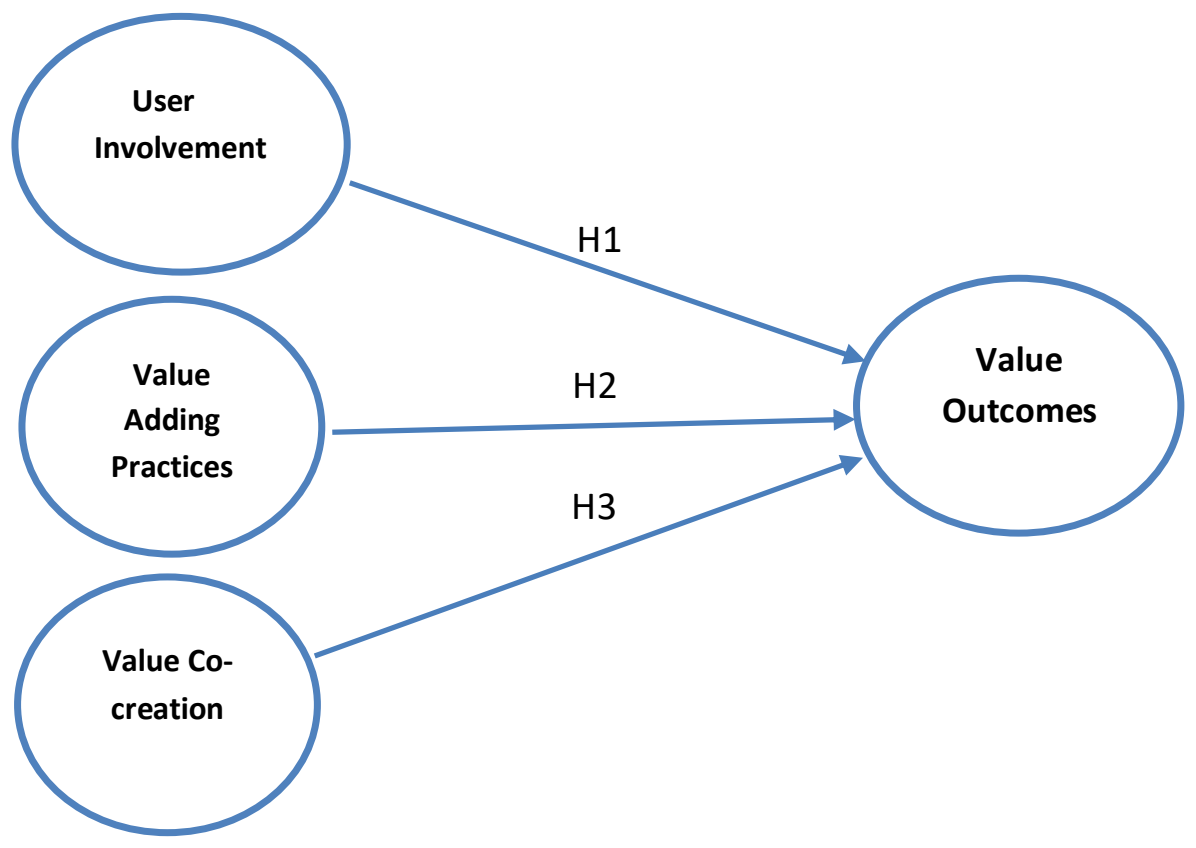

Figure 1. Conceptual model.

\section{Methods}

This study adopted PLS-SEM using SmartPLS 3.0 software for data analysis [62], for three key reasons. Firstly, the goal of the research is to predict the value factors that influence the value outcomes in building maintenance. PLS-SEM is suitable for a research work that aims to predict key target constructs as compared to other types of SEM techniques, such covariance-based SEM (CB-SEM), which is more appropriate for theory confirmation or rejection $[63,64]$. Secondly, PLS-SEM is suitable for low sample sizes [63]. In this research, the population is considered low, with only 139 public hospitals in the country. Thirdly, PLS-SEM is also suitable for data that is not normally distributed [63], wherein this study, the data are nonparametric.

Our questionnaire survey collected the following information: (i) respondents' and hospitals' backgrounds; (ii) value factors; (iii) value outcomes of hospital building maintenance. Variables were developed through the adaptation from the literature review and the synthesis of previous studies on value concepts. To present greater discriminant and reliability value, a 6-point Likert scale was used in this questionnaire, ranging from $1=$ strongly disagree to $6=$ strongly agree [65].

Face-to-face pre-tests were conducted to detect possible problems, bias, ambiguity, or unsuitability in the questionnaire $[66,67]$. Four respondents were involved, comprising an ex-monitoring consultant of hospital FM, a senior academic, a maintenance manager of a public hospital, and an ex-liaison officer of a public hospital. They were chosen based on experience and expertise either academically or in terms of hospital maintenance. Minor amendments were then made to improve the questions.

Target respondents were engineers from the Engineering Unit in the public hospitals. They were the person-in-charge to monitor, supervise, and control the hospital support services provided by the concession companies [68]. Besides, their roles also include assigning tasks, coordinating, and guiding the appointed users who were involved in the maintenance process. They are the most suitable respondents for the survey in this study.

Our study has attempted to cover all public hospitals in the country with a total of 139 hospitals (excluding medical institutions). The list was identified from the official webpage of the Ministry of Health, Malaysia [13]. The census method was applied, as this was suitable based on our well-defined, accessible, and small population [69]. The questionnaire survey was conducted via an online platform, as it was easier to administer 
and could reach a wide geographical coverage. Follow-ups via telephone calls were made as a reminder to increase the response rate.

\section{Proposed Model}

A value-based building maintenance model consists of four reflective constructs: user involvement, value add, value co-creation, and value outcomes, as shown in Figure 2. Value outcomes is an endogenous construct, while the other three constructs are exogenous. The assessment of the model consists of two steps: assessment of the measurement model (in this study, only reflective models were designed), followed by validation of the structural model. These steps are explained in the subsequent section. The main objective of PLS-SEM is to estimate the path coefficients that maximize the coefficient of determination $\left(R^{2}\right)$ of the endogenous construct. In this study, the endogenous construct is value outcomes. A higher value of $R^{2}$ indicates higher predictive accuracy [64]. The value ranges from 0 to 1 , with values of $0.26,0.13$ or 0.02 described as substantial, moderate, or weak, respectively, according to Cohen (1989) cited in [63]. The effect size $f^{2}$ measures changes in $\mathrm{R}^{2}$ due to the omission of the exogenous construct from the model, to assess its impact on the endogenous construct. The effect size $f^{2}$ value of $0.35,0.15$ or 0.02 indicate substantial, medium, and small effect size, respectively [63].

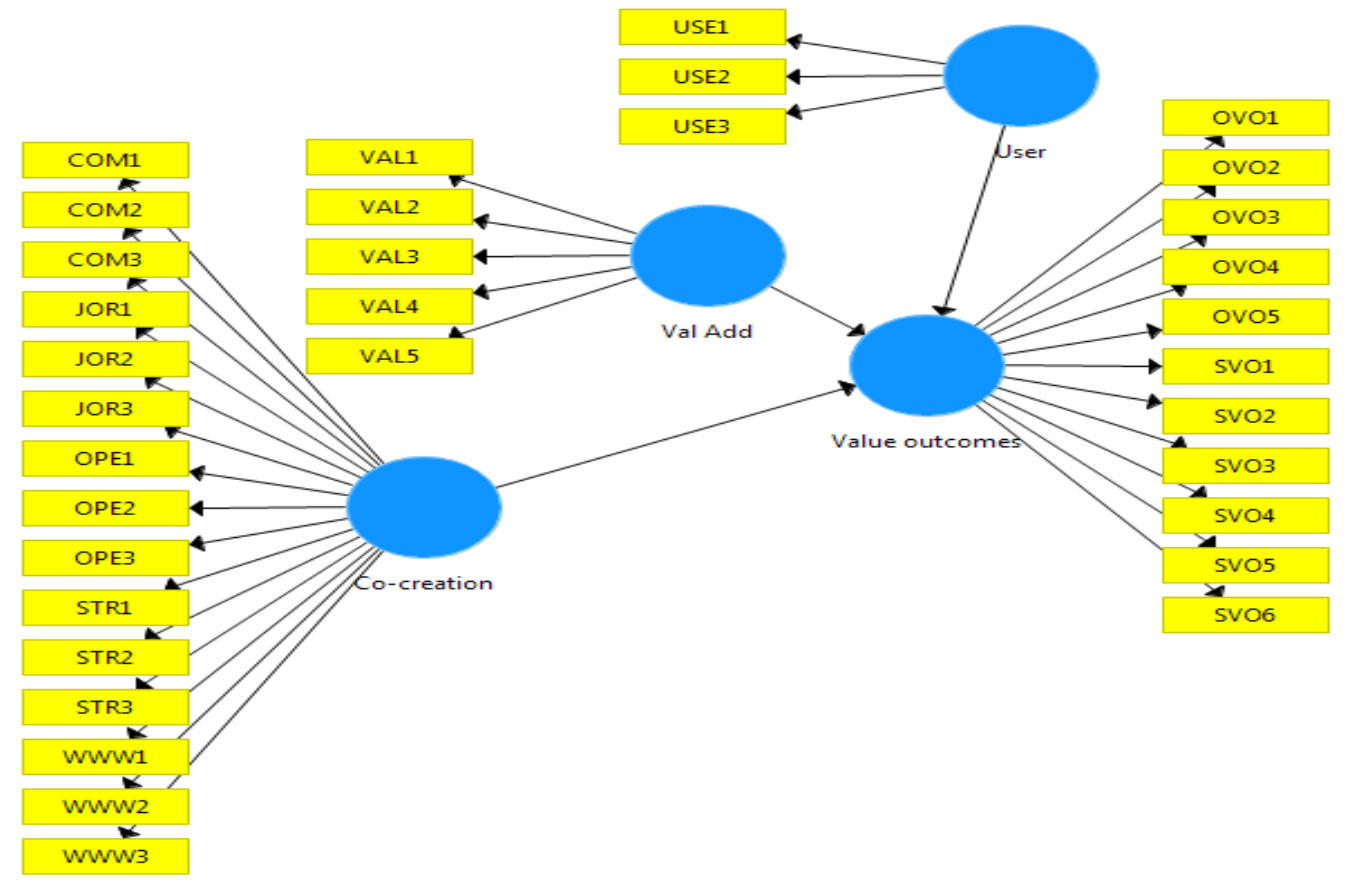

Figure 2. Proposed value-based building maintenance model.

\section{Results and Discussions}

From the 139 survey forms distributed, a total of 68 responses were collected, amounting to a $48.9 \%$ response rate. Out of this, 66 valid responses were accepted. The small sample size is due to the small number of public hospitals in the country, and limited number of target respondents in each hospital. Nonetheless, the 66 usable samples fulfilled the minimum sample criterion of 30 [63], and the 1:10 of structural paths directed to a construct ratio [70], in performing PLS-SEM analysis. Besides, the recommended sample size for $R^{2}$ ranges from 0.25 to 0.50 , with $5 \%$ probability of error, and a model with three arrows pointing to a construct required a sample size between 16 and 37 [64]. This study considered 66 valid samples, with an $R^{2}$ value of 0.423 .

The profile of respondents is depicted in Table 3. The average age of hospitals is 32 years, ranging from 4 to 133 years. The average number of beds is 274, ranging from 
40 to 1600 beds. The average number of staff members for FEMS is 50, ranging from 5 to 414 persons.

Table 3. Profile of respondents.

\begin{tabular}{|c|c|c|}
\hline & $\begin{array}{l}\text { Frequency } \\
(\mathrm{N}=66)\end{array}$ & $\%$ \\
\hline \multicolumn{3}{|l|}{ Position } \\
\hline (i) Engineer & 27 & 40.9 \\
\hline (ii) Assistant engineer & 39 & 59.1 \\
\hline Total: & 66 & 100 \\
\hline \multicolumn{3}{|l|}{ Education (Level) } \\
\hline (i) Diploma & 32 & 48.5 \\
\hline (ii) Bachelor degree & 31 & 47.0 \\
\hline (iii) Master degree & 3 & 4.5 \\
\hline (iv) Others & 0 & 0 \\
\hline Total: & 66 & 100 \\
\hline \multicolumn{3}{|l|}{ Academic qualification } \\
\hline (i) Mechanical engineering & 10 & 15.2 \\
\hline (ii) Electrical engineering & 9 & 13.6 \\
\hline (iii) Civil engineering & 42 & 63.6 \\
\hline (iv) Construction management & 1 & 1.5 \\
\hline (v) Biomedical & 1 & 1.5 \\
\hline (vi) Others & 3 & 4.6 \\
\hline Total: & 66 & 100 \\
\hline \multicolumn{3}{|l|}{ Years of Experience } \\
\hline Mean: & 5.19 & \\
\hline Standard deviation: & 2.593 & \\
\hline Range: & $1-14$ & \\
\hline
\end{tabular}

\subsection{Reflective Measurement Model}

The reflective measurement model was assessed in terms of internal consistency reliability, convergent validity, and discriminant validity. The composite reliability (CR) of this measurement model ranged from 0.756 to 0.927 , indicating internal consistency reliability [71]. In terms of indicator reliability/factor loading, the results show that the majority of indicators are above 0.4 of the minimum acceptable factor loadings, ranging from 0.552 to 0.861 [64]. Only 6 out of 34 indicators (17.6\%) were discarded due to low loadings; this is within the $20 \%$ limit of the overall number of indicators [72]. In terms of convergent validity, the final AVE of all constructs is above the minimum acceptable level of 0.5 . Table 4 summarizes the assessment of the measurement model.

Table 4. Measurement model.

\begin{tabular}{ccccc}
\hline Construct & Items & Loadings & AVE & CR \\
\hline User & USE1 & 0.685 & 0.509 & 0.756 \\
& USE2 & 0.682 & & \\
Val Add & USE3 & 0.769 & & 0.880 \\
& VAL1 & 0.757 & 0.595 & \\
& VAL2 & 0.857 & & \\
VAL3 & 0.771 & & \\
& VAL4 & 0.792 & & \\
& VAL5 & 0.668 & & \\
& COM1 & 0.597 & 0.502 & \\
& COM3 & 0.816 & & \\
& JOR3 & 0.741 & & \\
& OPE2 & 0.710 & & \\
& OPE3 & 0.621 & & \\
& & & & \\
& & &
\end{tabular}


Table 4. Cont.

\begin{tabular}{ccccc}
\hline Construct & Items & Loadings & AVE & CR \\
\hline STR1 & 0.738 & & \\
STR2 & 0.702 & & \\
VTR3 & 0.585 & & \\
& WWW2 & 0.678 & & \\
& WWW3 & 0.850 & 0.927 \\
& OVO1 & 0.633 & & \\
OVO2 & 0.815 & \\
OVO3 & 0.658 & \\
OVO5 & 0.715 & \\
& SVO1 & 0.728 & \\
SVO2 & 0.552 & \\
& SVO3 & 0.776 & \\
& SVO4 & 0.861 & \\
SVO5 & 0.855 & \\
\hline
\end{tabular}

Note: JOR1, COM2, JOR2, OPE1, OVO4, and WWW1 were discarded due to low loadings.

Discriminant validity of this measurement model was established via Fornell and Larcker's criterion [63]. Table 5 indicates that the square root of AVE of the construct is greater than inter-correlation with other constructs, and confirmed discriminant validity. The cross-loadings pattern established that loadings of items are higher with constructs that it is supposed to measure. To further verify this, Table 6 shows that the HeterotraitMonotrait ratio of correlations (HTMT) values are all below 0.85 which is the stringent criterion by Kline (2011), cite in [63].

Table 5. Discriminant validity using Fornell and Larcker's criterion.

\begin{tabular}{ccccc}
\hline & Co-Creation & User & Val Add & $\begin{array}{c}\text { Value } \\
\text { Outcomes }\end{array}$ \\
\hline Co-creation & 0.709 & & & \\
User & 0.272 & 0.713 & & \\
Val Add & 0.583 & 0.387 & 0.771 & 0.75 \\
Value Outcomes & 0.538 & 0.299 & 0.607 & \\
\hline
\end{tabular}

Table 6. Heterotrait-Monotrait ratio of correlations (HTMT) criterion.

\begin{tabular}{cccc}
\hline & Co-Creation & User & Val Add \\
\hline Co-creation & & & \\
User & 0.423 & & \\
Val Add & 0.654 & 0.562 & 0.668 \\
Value Outcomes & 0.54 & 0.393 & \\
\hline
\end{tabular}

\subsection{Validation of the Structural Model}

Validation of the structural model involves five essential steps to assess lateral collinearity, path coefficient, coefficient of determination, effect size to $R^{2}$, and Stone-Geisser $Q^{2}$ Predictive Relevance [63]. In terms of lateral collinearity, all three exogenous latent variables have a variance inflator factor (VIF) value below 3.3 suggested by Diamantopoulos and Siguaw (2006) cite in [63], which indicate that there is no collinearity problem. Table 7 shows the results of VIF. 
Table 7. Lateral collinearity assessment.

\begin{tabular}{cc}
\hline Construct & Value Outcomes (VIF) \\
\hline Value Outcomes & \\
Co-creation & 1.52 \\
User & 1.181 \\
Val Add & 1.655 \\
\hline
\end{tabular}

\subsection{Hypothesis Testing}

Three hypotheses, namely, H1 (User $\rightarrow$ Value Outcomes), H2 (Val Add $\rightarrow$ Value Outcomes), and H3 (Co-creation $\rightarrow$ Value Outcomes) were tested. The significance level was determined by referring to the t-statistics generated using the bootstrapping function in PLS 3.0, and path coefficients were assessed. The 95\% confidence interval was adopted.

The results show that for $\mathrm{H} 1$, the $t$-value of 0.569 is lower than the critical value of 1.645 , and the $p$ value of 0.285 is over 0.05 , indicating that this hypothesis is not supported. $\mathrm{H} 2$ has a $t$-value of 3.476 and a $p$ value of $0.000(p<0.01, t>2.33)$, while $\mathrm{H} 3$ has a $t$-value of 2.214 and a $p$ value of $0.014(p<0.05, t>1.645)$. These results indicate that both $\mathrm{H} 2$ and $\mathrm{H} 3$ were supported. Predictors of value co-creation and value add with $\beta=0.275$ and $\beta=0.423$, respectively, are positively related to value outcomes.

The coefficient of determination $\left(R^{2}\right)$ for value outcomes is 0.423 , which is considered substantial $\left(R^{2}>0.26\right)$ based on Cohen (1989) as cited in [63]. It explains $42.3 \%$ of the variance in value outcomes. In terms of the effect size to $R^{2}$, the $f^{2}$ value of 0.187 (greater than 0.15 ) indicates that value add has a medium effect size on value outcomes; while an $f^{2}$ value of 0.086 (greater than 0.02) according to Cohen (1988) as cited in [63], indicates that value co-creation has small effect size on value outcomes. Stone-Geisser $Q^{2}$ predictive relevance was tested using the blindfolding technique in PLS 3.0. The value of $Q^{2}$ of 0.195 is larger than 0 [64], indicating that predictive relevance is established in this model. Table 8 shows the results of hypothesis testing.

Table 8. Hypothesis testing.

\begin{tabular}{cccccccc}
\hline $\mathbf{H}$ & Relationship & Std Beta & Std Error & t-Value & $p$ Value & Decision & $\mathbf{f}^{2}$ \\
\hline H1 & User $\rightarrow$ Value Outcomes & 0.061 & 0.112 & 0.569 & 0.285 & not supported & 0.005 \\
H2 & Val Add $\rightarrow$ Value Outcomes & 0.423 & 0.117 & 3.476 & 0.000 & supported & 0.187 \\
H3 & Co-creation $\rightarrow$ Value Outcomes & 0.275 & 0.132 & 2.214 & 0.014 & supported & 0.086 \\
\hline
\end{tabular}

From the analysis, the following causal relationships were established:

1. Value-adding practices positively influence value outcomes.

2. Value co-creation positively influences value outcomes.

A revised model of the value-based building maintenance is shown in Figure 3.

The results from the hypothesis testing found that value-adding practices positively influence value outcomes with a medium effect size. The result is consistent with the case study by Okoroh et al. [29], where value-adding service providers achieved better service quality and enhanced corporate image through FM partnering arrangement in NHS trust. The results provide empirical justification to support their case study's outcome in terms of provision of innovative practices by service providers, value for money, and significant savings in the FM partnership. Besides, the results also support the work by Ali-Marttila et al. [50], that outsourced service providers which provide integrated solutions are more complete in their offering in the industrial maintenance context. Our study confirms the causal relations between value-adding practices which includes integrated service solution, to the value outcomes, in the context of outsourced hospital building maintenance. In hospitals, besides maintenance work of M\&E systems and plants, civil engineering works, operation and installation of engineering plants, the outsourced contractors also extend their services to include but not limited to technical advice, equipment loaning, reducing 
risks and hazards, and prolonging the life of the facilities. In addition, the results also affirm the responsiveness of service providers as one of the crucial aspects [38,58]. Overall, the finding confirms that by providing value-adding practices, contractors are able to improve their achievement of operational or strategic outcomes of hospitals. Ultimately, weaknesses of building maintenance such as lack of planned preventive maintenance [17], and various maintenance issues and user dissatisfaction could gradually be overcome. Besides, heavy reliance on supervision and monitoring by hospitals can be reduced to relieve over-straining of manpower resources [17,73].

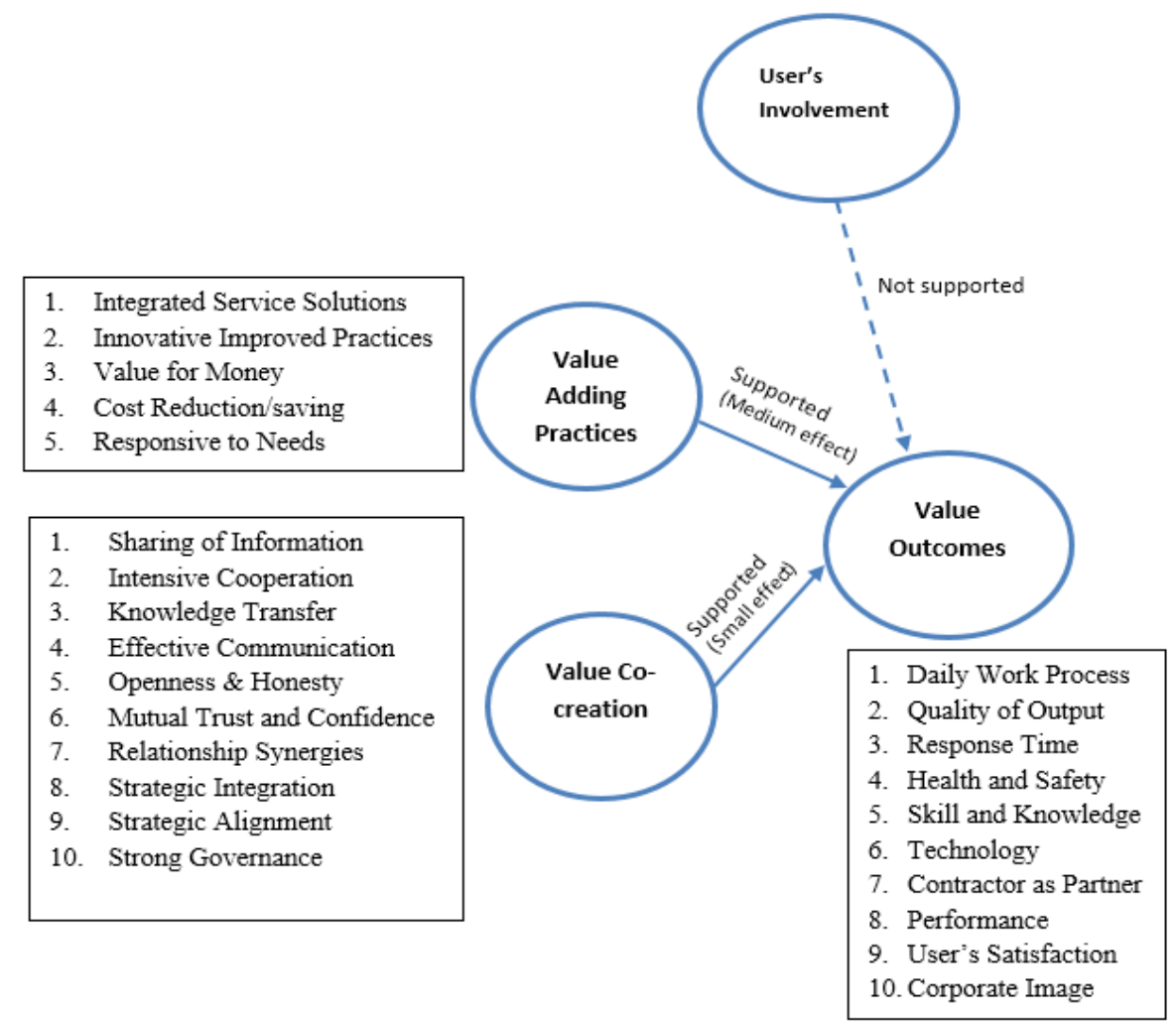

Figure 3. Revised value-based building maintenance model.

Hypothesis testing also found value co-creation positively influences value outcomes, but with a lower effect. It provides empirical evidence that supports the effort of collaborative working among various players to co-create values in the building maintenance context. The result is consistent with outcomes by Sun and Chen [56], where value co-creation was found to have a strong impact on outsourcing satisfaction in the IT field. The finding also supports the notion of sharing of resources of the service-dominant (S-D) logic by Vargo et al. [57], and findings on value co-creation in terms of sharing of information [52,53]. However, sharing of resources in terms of manpower and technology were not justified with the deletion of "Sharing of Manpower Resources" and "Joint Technology" items due to low loadings during PLS-SEM analysis. This can be explained due to the apparent demarcation of provision of manpower and technology by the contractor in the concession contract. However, past research on knowledge transfer notion is supported as a value co-creation practice in hospital maintenance [55,57]. Besides, this study also echoed the findings on the importance of openness and honesty, and mutual trust and confidence in outsourcing strategic partnerships [58]. In Malaysian public hospitals, value co-creation effort is evident in the Sustainable Energy Management Program (SEMP), where both monetary resources and electrical energy saving were achieved. There is a strong commitment from the Ministry of Health in terms of strategic alignment and strong leadership to pilot the projects of government hospitals. Personnel from concession companies and hospitals are trained and certified as Malaysian Certified Healthcare Facility Managers 
(CHFMs) [35]. This involves intensive cooperation amongst respective concession companies, engineers, and maintenance teams from hospitals, as well as joint resources and their effective communication.

However, it should be highlighted that the hypothesis "User involvement positively influences value outcomes" was not supported. The findings contradict past studies, which stressed the importance of user involvement $[38,48,59]$. This could be due to the lack of formal processes used to gather user expectation for decision-making during the early planning stage. Currently, user involvement is confined to implementation and postmaintenance stage such as job requests, complaints, and job completion verification [14], rather than early involvement [45]. User perception needs to be strategically aligned and linked to business processes from the pre-delivery, mid-delivery, and post-delivery stages [49]. Hence, without an understanding of user expectations at the early maintenance planning stage, it is challenging to deliver up to their satisfaction; this explains the reason user complaints are still rampant in public hospitals.

This study refines Value-based Maintenance Management Model by Olanrewaju et al. [38], by adding the value-based practices to their model, which did not explicitly address the relationships of the parties involved in building maintenance. Their model focused on management functions and served primarily as an operational manual for educational buildings. The value factors identified in this study can be assimilated into the management functions of their model, in order to enhance the achievement of value outcomes.

\section{Conclusions}

At present, the maintenance services of public hospitals in Malaysia are outsourced for better service quality and standardization. The performance of the five concessionaires serving the entire country actually reflects the corporate image of public healthcare facilities in the country. Using an online survey questionnaire, this research investigated the causal relationships between the value factors and value outcomes of building maintenance in public hospitals in Malaysia. The major findings revealed the significant influences which value-adding practice and value co-creation have on the value outcomes in hospitals. However, user involvement was not supported to influence value outcomes, which merits further investigations.

\subsection{Theoretical Implications}

This research expands the theoretical literature in value concepts by determining the causal relationships between value-adding practices and value co-creation to the value outcomes using PLS-SEM in an integrated model. Previous studies in value concepts were fragmented and investigated value concepts discretely in various fields and objectives. It reveals that value-adding practices by the maintenance service providers has greater effect to the achievement of value outcomes as compared to the effect that value co-creation contributes. This research provides an empirical and statistical assertion that acknowledges concession companies' essential roles in outsourced maintenance in public hospitals.

\subsection{Practical Implications}

Findings from this study inform maintenance service providers on the significant advantages of being proactive in adding value to their customers. By providing an integrated service solution, innovative improved practices, value for money, cost reduction/saving, and being responsive to users' needs, the contractors would be able to enhance their maintenance service delivery. Findings from this study would also be useful to policymakers in setting benchmarks for the selection of competent contractors, contract renewal, and performance monitoring. It provides justifications for maintenance organizations to shift from traditional, transactional, and contractual relationships, towards a collaborative networking culture. With the concession companies stationed round the clock in the hospital premises, there is a great opportunity for them to interact with the hospital maintenance 
teams and users. Within this setting, the "joint sphere" allows the providers and customers to interact, or jointly interact, directly or indirectly to co-create new value [51]. Value co-creation can be achieved with joint resources, operations integration, and open communication. In the long concession period, mutual understanding and strategic goals can be achieved through a win-win-win relationship.

\subsection{Limitations and Future Research}

While this research provides insights on value-based maintenance for hospital buildings, the research has some limitations. For instance, the user involvement factor was not statistically supported to influence the value outcomes. Therefore, further qualitative research such as in-depth interviews could be useful to further explain the quantitative results from this study. In addition, although value-adding practices and value co-creation were found to have a positive influence on value outcomes, the specific importance, and performance of each practice are not known. Hence, it is recommended that further research investigates the critical success factors in implementing the value-based approach in hospital maintenance. Lastly, this research only focused on public hospitals in Malaysia. It is recommended that future research can be designed to carry out comparison or parallel study on private hospitals to gather more insights and explore the best practices in both types of establishments.

Author Contributions: All authors contributed equally to all phases of conceptualization, methodology, investigation, and writing of the manuscript. All authors have read and agreed to the published version of the manuscript.

Funding: This research received no external funding.

Institutional Review Board Statement: Not applicable.

Informed Consent Statement: Informed consent was obtained from all subjects involved in the study.

Data Availability Statement: Further details regarding data can be obtained by contacting the author.

Conflicts of Interest: The authors declare no conflict of interest.

\section{References}

1. World Health Organisation. 2020. Available online: https://www.who.int/health-topics/hospitals\#tab=tab_2 (accessed on 7 April 2020).

2. Lavy, S.; Shohet, I.M. Integrated maintenance management of hospital buildings: A case study. Constr. Manag. Econ. 2004, 22, 25-34. [CrossRef]

3. Adenuga, O.; Ibiyemi, A. An Assessment of the State of Maintenance of Public Hospital Buildings in Southwest Nigeria. Constr. Econ. Build. 2009, 9, 51-60. [CrossRef]

4. Olanrewaju, A.L.; Wong, W.F.; Yahya, N.N.-H.N.; Im, L.P. Proposed research methodology for establishing the critical success factors for maintenance management of hospital buildings. Int. Symp. Green Sustain. Technol. 2019, 2157, 020036. [CrossRef]

5. Codinhoto, R.; Tzortzopoulos, P.; Kagioglou, M.; Aouad, G.; Cooper, R. The impacts of the built environment on health outcomes. Facilities 2009, 27, 138-151. [CrossRef]

6. Loo, V.G.; Bertrand, C.; Dixon, C.; Vityé, D.; DeSalis, B.; McLean, A.P.H.; Brox, A.; Robson, H.G. Control of ConstructionAssociated Nosocomial Aspergillosis in an Antiquated Hematology Unit. Infect. Control. Hosp. Epidemiology 1996, 17, 360-364. [CrossRef]

7. Abisuga, A.O.; Famakin, I.O.; Oshodi, O.S. Educational building conditions and the health of users. Constr. Econ. Build. 2016, 16, 19-34. [CrossRef]

8. Enshassi, A.; Farida, E.S.; Suhair, A. Assessment of Operational Maintenance in Public Hospitals Buildings in the Gaza Strip. Int. J. Sustain. Constr. Eng. Technol. 2015, 6, 2180-3242.

9. Galán, M.H.; Edith, M.D. Management Audit Applied to the Maintenance Department in Hospital Facilities. Ing. Mec. 2017, 20, 152-159.

10. Salleh, N.M.; Salim, N.A.A.; Jaafar, M.; Sulieman, M.Z.; Ebekozien, A. Fire safety management of public buildings: A systematic review of hospital buildings in Asia. Prop. Manag. 2020, 38, 497-511. [CrossRef]

11. Shastri, B.A.; Raghav, Y.S.; Sahadev, R.; Yadav, B.P. Analysis of Fire Protection Facilities in Hospital Buildings. In Advances in Fire and Process. Safety; Siddiqui, N.A., Tauseef, S.M., Abbasi, S.A., Rangwala, A.S., Eds.; Springer Nature: Singapore, 2018; pp. 183-190. [CrossRef] 
12. Malaysia Productivity Corporation. Reducing Unnecessary Regulatory Burdens on Business: Private Hospitals. 2014. Available online: http:/ / www.mpc.gov.my/reducing-unnecessary-regulatory-burdens-rurb-2/ (accessed on 2 January 2021).

13. Ministry of Health Malaysia. Healthcare Facilities (Government). 2019. Available online: http://www.moh.gov.my/ (accessed on 22 February 2020).

14. Fan, H.P. Privatization of Facility Management in Public Hospitals: A Malaysian Perspective; Patridge Publishing: Singapore, 2016.

15. Baba, M.; Abdul, H.M. A Conceptual Contract Framework for Research to Develop a Contract Framework for Outsourcing of Facilities Management in Malaysian Hospitals; IRERS: Kuala Lumpur, Malaysia, 2008.

16. Ali, M.; Mohamad, W.M.N.B.W. Audit assessment of the facilities maintenance management in a public hospital in Malaysia. J. Facil. Manag. 2009, 7, 142-158. [CrossRef]

17. National Audit Department Malaysia. Auditor General's Report 2015 Series 2; National Audit Department Malaysia: Putrajaya, Malaysia, 2016.

18. Mustapa, F.D.; Muzani, M.; Fuziah, I.; Kherun, N.I. Outsourcing in Malaysian Healthcare Support Services: A Study on the Causes of Increased Operational Costs. In Proceedings of the International Conference on Construction Industry, Sumatra Barat, Indonesia, 21-24 June 2006.

19. Ministry of Health Malaysia. Malaysia National Health Accounts; Health Expenditure Report 1997-2017; Planning Division, MOH: Putrajaya, Malaysia, 2019.

20. Yousefli, Z.; Nasiri, F.; Moselhi, O. Healthcare facilities maintenance management: A literature review. J. Facil. Manag. 2017, 15, 352-375. [CrossRef]

21. Lavy, S.; Shohet, I.M. On the effect of service life conditions on the maintenance costs of healthcare facilities. Constr. Manag. Econ. 2007, 25, 1087-1098. [CrossRef]

22. Al-Zubaidi, H. Assessing the Demand for Building Maintenance in a Major Hospital Complex. Prop. Manag. 1997, 15, 173-183. [CrossRef]

23. Vanzanella, C.; Fico, G.; Arredondo, M.T.; Delfino, R.; Viggiani, V.; Triassi, M.; Pecchia, L. Interactive management control via analytic hierarchy process: An empirical study in a public university hospital. J. Int. Bus. Entrep. Dev. 2015, 8, 144. [CrossRef]

24. Mustapha, Z.; Justice, A. Building Maintenance Systems of Public Health Institutions in Ghana: A Case Study of La General Hospital. J. Constr. Proj. Manag. Innov. 2011, 1, 155-166.

25. Amankwah, O.; Choong, W.-W.; Mohammed, A.H. Modelling the influence of healthcare facilities management service quality on patients satisfaction. J. Facil. Manag. 2019, 17, 267-283. [CrossRef]

26. Pheng, L.S.; Rui, Z. Service Quality for Facilities Management in Hospitals; Springer: Singapore, 2016. [CrossRef]

27. Jandali, D.; Sweis, R. Factors affecting maintenance management in hospital buildings. Int. J. Build. Pathol. Adapt. 2019, 37, 6-21. [CrossRef]

28. Yousefli, Z.; Nasiri, F.; Moselhi, O. Maintenance workflow management in hospitals: An automated multi-agent facility management system. J. Build. Eng. 2020, 32, 101431. [CrossRef]

29. Okoroh, M.; Gombera, P.; John, E.; Wagstaff, M. Adding value to the healthcare sector-A facilities management partnering arrangement case study. Facilities 2001, 19, 157-164. [CrossRef]

30. Manaf, N.H.A. Quality management in Malaysian public health care. Int. J. Heal. Care Qual. Assur. 2005, 18, 204-216. [CrossRef]

31. Ghani, A.; Zaid, M.; Abd, Z.; Ibrahim, I.; Musa, Z. Defining the Critical Success Factor in FM Malaysian Healthcare Sector. In Proceedings of the 3rd International Building Control Conference, Kuala Lumpur, Malaysia, 21 November 2013.

32. Ahmad, P.; Nur, A.; Mat, N.A.; Mohd, A.; Janice, L.Y.M.; Mohd, N.J.; Abdul, H.M. Critical Success Factors for Facilities Management Implement in the Healthcare Industry. Int. J. Real Estate Stud. 2017, 11, 69-83.

33. Rani, N.A.A.; Baharum, M.R.; Akbar, A.R.N.; Nawawi, A.H. Perception of Maintenance Management Strategy on Healthcare Facilities. Procedia Soc. Behav. Sci. 2015, 170, 272-281. [CrossRef]

34. Omar, M.F.; Ibrahim, F.A.; Omar, W.M.S.W. Key Performance Indicators for Maintenance Management Effectiveness of Public Hospital Building. MATEC Web Conf. 2017, 97, 01056. [CrossRef]

35. Abdullah, M.S.I.; Noor, M.A.R.; Tauran, Z.A.Z.; Khairul, A.K. Latest Development on Sustainability Programme Initiatives in Malaysian Healthcare Facility Management. In Proceedings of the 37th Conference of the ASEAN Federation of Engineering Organisations, Jakarta, Indonesia, 11-15 September 2019.

36. Kamaluddin, K.A.; Muhammad, S.I.A.; Yang, S.S. Development of Energy Benchmarking of Malaysian Government Hospitals and Analysis of Energy Savings Opportunities. J. Build. Perform. 2016, 7, $72-87$.

37. Sahamir, S.R.; Rozana, Z. Green Assessment Criteria for Public Hospital Building Development in Malaysia. Procedia Environ. Sci. 2014, 20, 106-115. [CrossRef]

38. Olanrewaju, A.L.; Abdul-Aziz, A.-R. Building Maintenance Processes and Practices: The Case of a Fast Developing Country; Springer: Singapore, 2015. [CrossRef]

39. Awang, N.A.; Chua, S.J.L.; Ali, A.S. Building Condition Assessment Focusing on Persons with Disabilities' Facilities at Hospital Buildings. J. Des. Built Environ. 2017, 17, 73-84. [CrossRef]

40. Ab Ghani, M.Z.; Srazali, A. Comparative Review of Design Requirements for Natural Smoke Ventilation in Hospital Buildings. J. Malays. Inst. Plan. 2018, 16, 334-344. [CrossRef] 
41. National Audit Department Malaysia. Auditor General's Report 2015 Series 1; National Audit Department Malaysia: Putrajaya, Malaysia, 2016.

42. Carvalho, M.; Hemananthani, S.; Rahimy, R.; Loshana, K.S. Auditor-General' s Report 2017: Alor Gajah Hospital Comes under Scrutiny. The Star Online, 6 August 2018. Available online: https://www.thestar.com.my/news/nation/2018/08/06/ag-report2017-alor-gajah-hospital-comes-under-scrutiny (accessed on 11 October 2019).

43. Olanrewaju, A.; Fang, W.W.; Tan, S.Y. Hospital Building Maintenance Management Model. Int. J. Eng. Technol. 2018, 7, 747-753. [CrossRef]

44. Prahalad, C.K.; Ramaswamy, V. Co-creating unique value with customers. Strat. Leadersh. 2004, 32, 4-9. [CrossRef]

45. Jensen, P.A.; Maslesa, E. Value based building renovation-A tool for decision-making and evaluation. Build. Environ. 2015, 92, 1-9. [CrossRef]

46. Abdul-Lateef, O.A. Quantitative Analysis of Criteria in University Building Maintenance in Malaysia. Constr. Econ. Build. 2010, 10, 51-61. [CrossRef]

47. Olanrewaju, A.L.; Mohd, F.K.; Arazi, I. Validation of Building Maintenance Performance Model for Malaysian Universities. Int. J. Hum. Soc. Sci. 2011, 6, 159-163.

48. Zulkarnain, S.H.; Emma, M.A.Z.; Rahman, M.Y.A.; Nur, K.F.M. A Review of Critical Success Factor in Building Maintenance Management Practice for University Sector. Int. J. Civ. Environ. Struct. Constr. Archit. Eng. 2011, 55, 215-219. [CrossRef]

49. Tucker, M.; Smith, A. User perceptions in workplace productivity and strategic FM delivery. Facilities 2008, 26, 196-212. [CrossRef]

50. Ali-Marttila, M.; Marttonen-Arola, S.; Kärri, T.; Pekkarinen, O.; Saunila, M. Understand what your maintenance service partners value. J. Qual. Maint. Eng. 2017, 23, 144-164. [CrossRef]

51. Grönroos, C.; Voima, P. Critical service logic: making sense of value creation and co-creation. J. Acad. Mark. Sci. 2013, 41, 133-150. [CrossRef]

52. Coenen, C.; Alexander, K.; Kok, H. Facility management value dimensions from a demand perspective. J. Facil. Manag. 2013, 11, 339-353. [CrossRef]

53. Bititci, U.S.; Martinez, V.; Albores, P.; Parung, J. Creating and managing value in collaborative networks. Int. J. Phys. Distrib. Logist. Manag. 2004, 34, 251-268. [CrossRef]

54. Martinez, V.; Bititci, U.S. Aligning value propositions in supply chains. Int. J. Value Chain Manag. 2006, 1, 6-18. [CrossRef]

55. Joshi, K.P.; Murthy, C. Determining Value Co-Creation Opportunity in B2B Services. In Proceedings of the 2011 Annual SRII Global Conference (SRII 2011), San Jose, CA, USA, 29 March-2 April 2011; pp. 674-684. [CrossRef]

56. Sun, S.Y.; Li, S.C. Achieving Value Co-Creation in IT Outsourcing. J. Int. Technol. Inf. Manag. 2016, 25, 1-18.

57. Vargo, S.L.; Maglio, P.P.; Akaka, M.A. On value and value co-creation: A service systems and service logic perspective. Eur. Manag. J. 2008, 26, 145-152. [CrossRef]

58. Dibley, A.; Moira, C. How to Implement. Best Practice in Strategic Partnerships: An. Outsource Supplier and Client Perspective; The Henley Centre for Customer Management: London, UK, 2011.

59. Jensen, P.A. The Facilities Management Value Map: a conceptual framework. Facilities 2010, 28, 175-188. [CrossRef]

60. Dibley, A.; Clark, M. Value Co-Creation in Strategic Partnerships: An Outsourcing Perspective. In Service-Dominant Logic., Network $\mathcal{E}$ Systems Theory and Service Science: Integrating Three Perspectives for a New Service Agenda; Polese, F., Ed.; Henle Business School: Napoli, UK, 2005.

61. Gummerus, J. Value creation processes and value outcomes in marketing theory. Mark. Theory 2013, 13, 19-46. [CrossRef]

62. Christian, M.R.; Wende, S.; Becker, J.M. SmartPLS 3; SmartPLS GmbH: Bönningstedt, Germany, 2015.

63. Ramayah, T.; Jacky, C.; Francis, C.; Hiram, T.; Mumtaz, A.M. Partial Least Squares Structural Equation Modeling (PLS-SEM) Using SmartPLS 3.0., 2nd ed.; Pearson Malaysia Sdn. Bhd.: Kuala Lumpur, Malaysia, 2018.

64. Hair, J.F.G.; Tomas, M.H.; Christian, R.; Marko, S. A Primer on Partial Least Squares, 2nd ed.; SAGE Publications, Inc.: Los Angeles, CA, USA, 2017.

65. Chomeya, R. Quality of Psychology Test between Likert Scale 5 and 6 Points. J. Soc. Sci. 2010, 6, 399-403.

66. Willis, G.B. Questionnaire Pretesting. In The SAGE Handbook of Survey Methodology; Christof, W., Dominique, J., Tom, W., Yang, C.F., Eds.; SAGE Publishing Ltd.: London, UK, 2016; pp. 359-381.

67. Collins, D. Pretesting Survey Instruments: An Overview of Cognitive Methods. Quality 2009, 12, 229-238. [CrossRef]

68. National Audit Department Malaysia. Auditor General's Report 2014 Series 3; National Audit Department Malaysia: Putrajaya, Malaysia, 2015.

69. Mooi, E.; Marko, S. Concise Guide to Market. Research: The Process, Data and Methods Using IBM SPSS Statistics; Springer: Berlin/Heidelberg, Germany, 2011.

70. Barclay, D.W.; Christopher, A.H.; Ronald, T. The Partial Least Squares Approach to Causal Modeling: Personal Computer Adoption and Use as Illustration. Technol. Stud. 1995, 2, 285-309.

71. Hair, J.F.; Risher, J.J.; Sarstedt, M.; Ringle, C.M. When to use and how to report the results of PLS-SEM. Eur. Bus. Rev. 2019, 31, 2-24. [CrossRef] 
72. Hair, J.F.; William, C.B.; Barry, J.B.; Rolph, E.A.; Tatham, R. Multivariate Data Analysis, 7th ed.; Pearson Prentice Hall: Hoboken, NJ, USA, 2010

73. Aliman, K.H. Audit Finds Malaysian Hospitals Understaffed, Underfunded and Overcrowded. The Edge Markets. 15 July 2019. Available online: https://www.theedgemarkets.com/article/audit-finds-malaysian-hospitals-understaffed-underfunded-andovercrowded\# (accessed on 11 October 2019). 